\title{
The Use of Scramble Word Game to Develop Students Competence in Pronoun at MTsN 3 Sidoarjo
}

\author{
Mukhoiyaroh \\ Mathematics Education \\ UIN Sunan Ampel \\ Surabaya, Indonesia \\ Luluk Isnainiyah \\ English Language Education Department \\ UIN Sunan Ampel \\ Surabaya, Indonesia
}

\author{
Syilviani Budiarti \\ English Language Education Department \\ UIN Sunan Ampel \\ Surabaya, Indonesia \\ Eryna Pratiwi \\ English Language Education Department \\ UIN Sunan Ampel \\ Surabaya, Indonesia
}

\author{
Irma Fahriani \\ English Language Education Department \\ UIN Sunan Ampel \\ Surabaya, Indonesia
}

\begin{abstract}
Students with different intellectual have limitations to specify to be with a subject in Pronoun. That is why they feel difficult to arrange the sentences. In this research, classroom action research is designed to develop students by implementing scramble word game. This research aims 1) to describe the scramble word game can develop students competence in Pronoun or not 2) to identify the situations when scramble word game implement in the class. This research used classroom action research was done in the students of seventh $\mathrm{C}$ grade of MTsN 3 Sidoarjo. The teacher implemented a scramble game method to develop students' competence in Pronoun. This research provided pre-test before treatment and post- test after the treatment. The researcher obtained the data through observation and documentation. The findings of this research There were 26 students got less score than 60 in cycle 1, and the number decreased to 10 students in cycle 2 . Besides, there were four students got scores more than 60 in cycle 1 , and it increased to 32 students in cycle 2 . It increased on the number of students who achieved equal to or more than 60 as many as 28 students from pre-test or cycle 1 to post-test or cycle 2 . It meant that the result had met the criteria of success. Thirty-two students got the expected score. If we compared to the result in pre- cycle 1 , there was a difference. In cycle 2 , there was an unexpected significant improvement. At the end of this research, it is expected to be implemented other researcher to achieve a better teaching and learning process.
\end{abstract}

Keywords: scramble, students' competence, pronoun

\section{INTRODUCTION}

English has been taught in junior high school to provide students with the necessary knowledge and vocabulary of an international language. The improvement of students' vocabulary in learning English depends on the teachers' strategy. Teaching English in junior high school different from teaching English in primary school. The main problem in teaching English in school is students less motivation because of the students' limitation of vocabulary. In learning English, vocabulary is one of the essential parts for mastering (Tahir, 2012).

Moreover, the students of the English language often have misappropriated the roles Pronouns when constructing sentences. The success in learning English is characterized by the mastery of vocabulary, including the understanding of the English pronouns. Students can describe everything they will talk about without using grammar. However, they cannot make a sentence without knowing the vocabulary and Pronoun.

Vocabulary acquisition is the main task of language skills such as listening, speaking, reading, and writing. It means all of the skills cannot go without vocabulary. Many English teachers find students at school do not have much vocabulary so that it is difficult for them to match Pronoun with the subject. This problem possibly implies that the students will get a low score in English subjects, especially in materials dealing with a pronoun. There were many factors which caused the problem. Some of the students in junior high school still had less vocabulary, and they do not understand teacher explanation. Moreover, students still feel difficult to communicate and too lazy to learn English. The teacher should know the problem and find a solution to overcome the problem.

Some researchers have conducted studies on the use of Scramble game in improving English skills. Salfa et al., in their study found out whether the use of scramble game showed any different or significant improvement towards the student's vocabulary and to reveal the motivation between the pre-test and post-test of the student's vocabulary after they have got treatment. The result of this research was the use of scramble game in teaching vocabulary improved the student's 
vocabulary. Fahrizal carried out a study to investigate the effect of scramble game on the seven grade students' vocabulary mastery at SMP PAB 19 Manunggal. At the end of this research, there was an effect of scramble game in the seven grade students' vocabulary at SMP PAB 19 Manunggal.

Noverita et al. described the effects of the scramble games towards the capability of sentence composition for students with intellectual disability. The result of this study deals with the scramble game effect toward the students' capability of composing a sentence. Rudhatul Jannah et al. describe the use of scramble using the media to improve reading and writing ability at elementary school. The result of this study focused on reading and writing ability.

All of the previous studies have not yet found out the use of scramble word game to develop students' competence in Pronoun. Furthermore, the aims of this research is: 1) to describe the scramble word game can develop students competence in Pronoun or not 2) to identify the situations the scramble game implement in the class. As the subject of this research will involve the students of seventh C grade of MTsN 3 Sidoarjo. At the end of this research are expected to be implemented for the teacher to achieve a better teaching and learning process. Moreover, this research will be beneficial for other researchers since it gives more references when they are going to conduct research dealing with a similar topic.

\section{REVIEW OF LITERATURE}

In learning a foreign language, we have to learn vocabulary because it is an essential part of the language. There are several definitions of vocabulary. Hornby says that vocabulary fare, 1) All the words that a person knows or uses; 2) All the words in a particular language; 3) The words that the people use when they are talking about a particular subject (As Hornby, 2000). Therefore vocabulary has many fruitful for students who want to learn English. Vocabulary mastery is crucial because it makes a sentence more meaningful (Tahir, 2012).

Learning vocabulary, we have to know the meaning and understand the sentence context. Vocabulary mastery is a person's ability to recognize, understand and use a word correctly by listening, speaking, reading and writing. To better understand, Tarigan (1994:446) state that vocabulary is 1) a component that contains information about meaning and application of word; 2) the wealth belongs to a speaker, writer or a language; 3 ) a list of terms arranged like a dictionary for practical.

When learning vocabulary, learners need to know the meaning of the words used. It is essential also to know how to use them in a sentence. Wilkins (1972:130) states that vocabulary learning is learning to differentiate the progress of meaning word in a target. Vocabulary has a very significant role in language learning. Vocabulary mastery is very influential for language skills. There are four types of vocabulary. They are verb, adverb, noun, and adjective. Taken from the book entitled English Grammar, there are eight classes of a word as below:

\section{Noun}

A noun is a word used for referring to anything including a person, animal, object, place, situation, quality or idea.

Example: Take your drawing book, please!

Alif is listening to the radio.

\section{Pronoun}

A pronoun is a form of a word that can replace nouns.

Example: Cinta says that she has finished the work.

3. Verb

Verb are words that describe an activity carried out

Example e: Alfian studies lesson mathematic.

\section{Adjective}

An adjective is a word to describe or modify noun or Pronoun

Example: Rizki is a smart boy.

Pronouns are considered as grammatical items of the system, which may function in place of nouns and noun phrases (Eka D, 2008). Apart from the pronouns, other grammatical items of the group include the preposition, conjunction, interjection - other items belonging to the closed system in English (this, that, etc.). The specific and nonspecific modifiers ('the' and 'a') sometimes referred traditional terms and regarded as the definite and indefinite articles. Characteristics not permitting a consecutive occurrence of its members in the structure of expression were shared with others. A writer uses pronouns to avoid repetition of unnecessary words. In other words, Pronoun is a grammatical item used in substitute for a noun.

In a learning process, methods for learning so various. The scramble word game is one method to improve students' learning and speed of though (Huda M, 2003). Their method needs students to combine the right brain and the left brain. In this method, students not only asked the question but also to guest quickly questions that are available in random conditions. The accuracy and speed of thought in answering the question lead to points in the scramble word game. The speed of the students in answering the question determines their scores. Learning method with scramble is a derivative of cooperative learning. Scramble word game can be done in a learning process using critical thinking so that it is easier to search for problem-solving. Scramble word game provides an answer sheet accompanied by alternative answers which are already there. Students are expected to look for the answers and ways of settlement of the matter. The scramble game is 
essentially an activity to acquire specific skills, through an exciting way.

Scramble is for the type of games which train development and improvement of vocabulary thinking insight. Scramble word game used to arrange the words and letters that are jumbled and the students need to form a word which has meaning. The words are randomized so that students can think of a way to solve it. Scramble word game has several advantages. Firstly, it makes students more creative in learning and thinking. At the same time, the students also learn the material in a more relaxed situation without pressure since the method allows them to learn while playing. The second advantage is that the game can foster critical thinking which makes students more competitive in learning. Third, it makes students have a responsibility for their answers. On the other hand, scramble word game has disadvantages, 1) learning method is complicated in term; 2) requires a long time; 3 ) learning method is challenging to implement; 4) class can be noise.

\section{METHODOLOGY}

The method of this research is CAR (Classroom Action Research). Burn states Action research is the application of facts to find practical problem-solving in a social situation by improving the quality of action that involves the co-operation as well as collaboration between researchers, practitioners and also laypeople (Burns Anne, 1999). According to Kemmis and Wilkinson, even though the process of action research is inadequately put into description in terms of its mechanical sequencedsteps, it is commonly considered to deal with a spiralform of self-reflective cycles consisting of planning a change, acting and observing the process and consequences of the change, reflecting on these processes and consequences, and then re- planning, and so forth (Kemmis, et al, 2004). Therefore the procedures of action research cover activities, such as identifying problems and planning, implementing action, observing, and reflecting. This research used Classroom Action Research (CAR) because this research aims to describe the scramble method can develop students competence in Pronoun.

The subject of this research was seventh grade, class $\mathrm{C}$ of MTsN Sidoarjo. Their ages are between 12-13 years old, consisting of 36 students. The researcher chose this class because they have the lowest grade of Pronoun compared to other classes. For this research test and observation are employed. The first test sheet was used to find out the competence of the students' Pronoun without any treatment. The second test was used scramble word game to find out the improvement of the students' Pronoun.

\section{Planning}

Firstly the researcher decided the topic of a lesson. Secondly, the researcher made a lesson plan and designed the steps in doing the action based on the treatment carried out. The researcher made the scenario of the teaching-learning process for the treatment using scramble word game. Firstly, the researcher prepared a test to find out the students' abilities to do Pronoun exercise using fill in the blank. Then, the second test, the researcher designed scramble word game in cycle 2 to find out students' improvement to do Pronoun exercise. This research is successful if it can exceed the criterion set previously. However, it will be unsuccessful if it cannot meet the criterion.

Furthermore, this research can be successful when there were two criterions. First, there were $70 \%$ numbers of students could achieve some vocabulary improvement scores from the pre- test up to the time of giving the post-test with treatment in cycle two or they could pass the target score of the Minimum Completeness Criteria (KKM). The KKM that must be achieved by each student is 60 (sixty) adjusted from the curriculum. If the criteria of the action success achieved, it means that the Classroom Action Research (CAR) action can be said to be successful, but if the result does not meet the criteria, alternative actions will be carried out in the next cycle.

\section{Acting}

In this step, this research did the planning that had made on the planning step. The treatment was the scramble word game of Pronoun.

\section{Observing}

The observation occurred during the teaching and learning process on pronoun material. The researchers are observers in the classroom. The researcher observed and wrote down the process happen during the action. At the end of the meeting, this research gave the final test (post-test) to find out whether the students' Pronoun had improved through the use of Scramble word game or not. The researcher compared the result of the post-test with the pre-test result. The result of post-test also compared to the criteria of success. Therefore, the data analysis is for the reflection of the teacher.

\section{Reflecting}

In this step, the researcher reflected the cycle that had finished. The researcher evaluated the teaching-learning process. Then the researcher reflected by checking the result of the students' test. If the students' score was less than the success criteria, the cycle revised and done again for the next cycle using revised of the reflecting of the cycle before.

\section{RESULTS AND DISCUSSION}

The result of post-test in cycle 2 showed in this diagram:

Diagram 1 Students' Pronoun Score post-test in cycle 2 
Based on the data, we knew that the mean score of

\section{Student's Score}

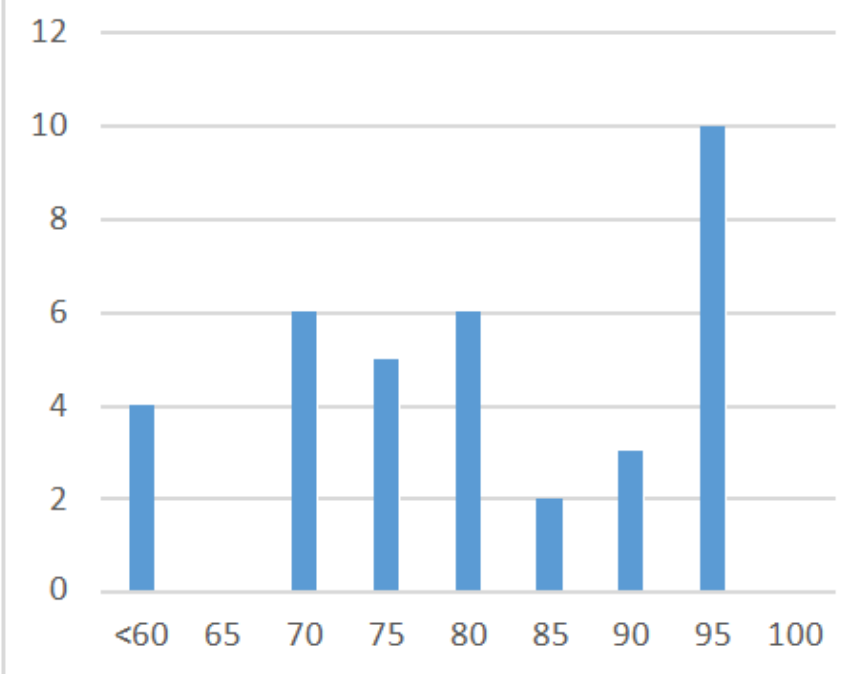

Based on the result of post-test in cycle 2, it showed that there were four students still low in Pronoun. It has been significantly reduced compared with the results of pre-cycle. We also could see that the lowest score was $<60$, while the highest score was 95 . from 36 students, there were four students got 65,6 students got 70,5 students got 70,6 students got 80,2 students got 85,3 students got 90, 10 studenta got 95 , and no one students got 100. based on rhe diagram, we know that the most-obtained score by the students was 90 .

Whereas to esstablish the number of students who have achieved a Minimum Completeness Criteria (KKM), can be described in the diagram below:

\section{Diagram 2 Students'Pronoun Achievement in}

Post-condition in Cycle 2

\section{Minimum Completeness Criteria} (KKM)

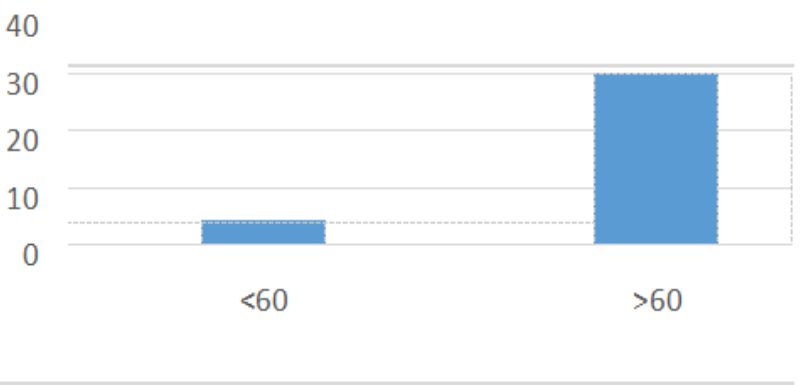

From the diagram, we know that students who got equal to or greater than 60 were 32 students and four students got less than score 60. Based on the previous description that the students were said to be complete if they achieved the Minimum Completeness Criteria (KKM) or got equal to or more than score 60, thus students who achieved the Minimum Completeness Criteria (KKM) in the cycle 2 were 32 students. students' Pronoun in cycle 2 was more than Minimum Completeness Criteria (KKM) and the number of students who were able to reach Minimum Completeness Criteria (KKM) more than the criteria of success in this research. It implied that the criterion has fulfilled in this cycle.

Furthermore, if we compared the research results in cycle 2 with pre-cycle, the result could be illustrated by the diagram below:

\section{Diagram 3 Students' Pronoun Achievement in}

\section{Pre-Test and Post-Test in Cycle 2}

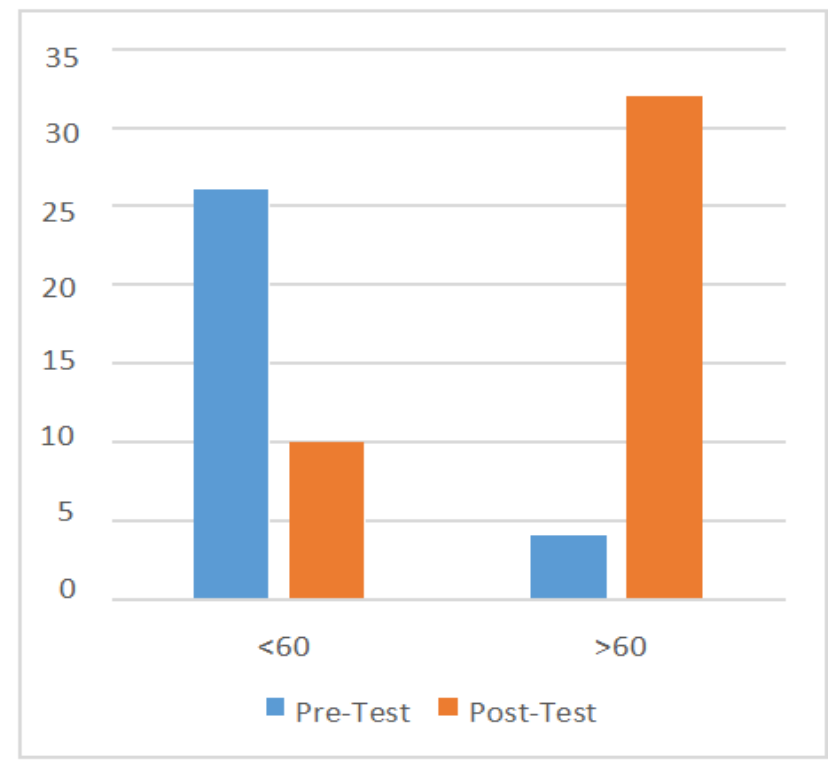

Based on the diagram above, there were 26 students got less score than 60 in cycle 1 , and it decreased to 10 students in cycle 2 . Besides, there were four students who got score more than 60 in cycle 1 , and it increased to 32 students in cycle 2. There was an increase in the number of students who achieved equal to or more than 60 as many as 28 students from pre-test or cycle 1 to post-test or cycle 2 .

\section{CONCLUSION AND RECOMMENDATION}

This research used CAR (Classroom Action Research). the number of the participant were 36 students from seventh $\mathrm{C}$ grade of MTs Negeri 3 Sidoarjo. Teh conclusion could see it was figured in this graphic and table below if scramble word ga,e is useful to develop students competence in Pronoun at MTsN 3 Sidoarjo. It is related to the data analysis of the students' vocabulary and grammar in pronoun achievement before implementing scramble word game and after implementing it. There were 26 students got less score than 60 in cycle 1 , and it decreased to 10 students in cycle 2 . Besides, four students got to score more than 60 in cycle 1 , and it increased to 32 students in cycle 2 . There was an increase in the number of students who achieved equal to or more than 60 as many as 28 students from pre-test or cycle 
[9] Tahir, S. B. (2012). Teaching English as World Language: Pengajaran Bahasa Inggris. Jakarta: Media Pustaka Qalam.

[10] Tarigan, G. H. (1994). Membaca Sebagai Suatu Keterampilan Berbahasa. Bandung: Penerbit Angkasa.

[11] Wilkins. (1972). Linguistics in Language Teaching . London: University College.

1) For the teacher

The result of this research can be used by the teacher in the teaching-learning process as one the alternative to make students easier when they learn about the Pronoun.

2) For the students

By applying this game, the researcher expects that the students will be able to match the subject and 'to-be' in Pronoun correctly.

3) Future researchers

The result of this research, it is expected that this research becomes a reference in conducting other researchers, especially related to teaching pronoun for junior high school.

\section{REFERENCES}

[1] Burns, A. (1999). Collaborative Action Research for English Language Teachers. Cambridge: Cambridge University Press.

[2] Eka, D. (2008). Elements of Grammar and Mechanics of the English Language. Nigeria: Samuf (Nigeria) Limited.

[3] Fahrizal, M. (2019). The Effect of Scramble Game on the Seven Grade Students' Vocabulary Mastery at SMP PAB 19 Manunggal.

[4] Hornby, A. (2000). Oxford Advanced Learner's Dictionary of Current English. New York: Oxford University Press .

[5] Huda, M. (2013). Model-Model Pengajaran dan Pembelajaran: Isu-Isu Metodis dan Paradigmatis. Yogyakarta: Pustaka Pelajar.

[6] Noverita Surya D, A. K. (2017, Janulary 1). The Effect of Scramble Game Towards the Ability of Composing Sentences for Students with Intellectual Disability. Journal of ICSAR, 1, 81-84.

[7] Salfa Umasugi, H. R. (2018, May). The Scramble Game in Improving Students' Vocabulary at the Seventh Grade of MTS LKMD SAWA.

[8] Stephen Kemmis, e. a. (2002). Action Research in

Practice. London and New York: Routledge. 